\title{
Digestibilidade aparente dos nutrientes da dieta completa peletizada e extrusada composta por diferentes fontes de fibra para equinosas
}

Katia Feltre, Alexandre Augusto de Oliveira Gobesso, Fernanda Rudolf Gonzalbo Garcia, Gabriela do Vale Pombo, Yasmin de Sales Pereira, Luiz Antonio Jorge de Moraes Filho, Bianca Petermann Moretti, Julio Cesar de Carvalho Balieiro

Faculdade de Medicina Veterinária e Zootecnia, Universidade de São Paulo (USP), Pirassununga, SP, Brasil

*Autor correspondente

e-mail: katiafeltre@yahoo.com.br

\section{Resumo}

O objetivo do trabalho foi aferir os efeitos do uso de dieta completa na digestibilidade aparente dos nutrientes em equinos, utilizando alimento peletizado e extrusado produzidos com três diferentes fontes de fibra. Foram utilizados oito equinos, machos castrados da raça Mini-Horse, com idade aproximada de 5 anos e peso médio de $140 \mathrm{~kg}$. As dietas foram divididas em dieta controle 50\% de volumoso (feno de Tifton 85) e $50 \%$ concentrado peletizado, fornecidos separadamente, e dieta completa peletizada e extrusada composta por $50 \%$ de volumoso (Tifton 85 , capim elefante ou rolão de milho) mais $50 \%$ concentrado em um único produto. Foram realizados quatro períodos de 20 dias (15 dias de adaptação e 5 dias para coleta total de fezes) em que o consumo diário individual adotado foi de 1,75\% do peso e a água ad libitum. Entre cada período, houve um intervalo (3 semanas) onde os animais receberam $2 \%$ do peso corporal em matéria seca de feno de Tifton 85, sal mineral e água ad libitum. Os animais e os tratamentos foram distribuídos aleatoriamente em dois Quadrados Latinos, balanceados e simultâneos, sendo Q1 (controle, capim elefante, rolão de milho e feno de Tifton 85 peletizados) e Q2 (controle, capim elefante, rolão de milho e feno de Tifton 85 extrusados). Foram avaliados os teores de matéria seca (MS), matéria orgânica (MO), proteína bruta (PB), matéria mineral (MM), extrato etéreo (EE), fibra em detergente neutro (FDN), fibra em detergente ácido (FDA) e amido. As amostras de fezes foram colhidas e acondicionadas em sacos plásticos protegidos da luz solar. As fezes foram recolhidas, pesadas, homogeneizadas e uma alíquota de 10\% (amostras simples) foi retirada e armazenada em freezer a $-20^{\circ} \mathrm{C}$. Ao término do experimento, todas as amostras simples de cada animal foram descongeladas e homogeneizadas, formando uma amostra composta da qual foi retirada uma porção de aproximadamente $300 \mathrm{~g}$. Todas as amostras (alimentos e fezes) foram submetidas à secagem $\left(65^{\circ} \mathrm{C}\right.$ ) $\mathrm{e}$ moídas em peneira de $1 \mathrm{~mm}$. Com base nos resultados bromatológicos, foram calculados os coeficientes de digestibilidade aparente da matéria seca (DAMS), proteína bruta (DAPB), extrato etéreo (DAEE), fibra 
em detergente neutro (DAFDN), fibra em detergente ácido (DAFDA) e matéria orgânica (MO). As fontes de fibra e os tipos de processamento não interferiram $(\mathrm{P}<0,05)$ nos coeficientes de digestibilidade aparente da PB (média de 69,59\%) e do EE (média 61,96\%). Porém, foi observado efeito $(\mathrm{P}<0,05)$ das fontes de fibra nos coeficientes de digestibilidade aparente da MS, FDN e da MO, sendo menores para o capim elefante em relação às demais fontes de fibra e ao controle, com médias de 59,17, 60,94 e 47,18\%, respectivamente. 0 coeficiente de digestibilidade aparente da FDN do feno de Tifton 85 e do controle foram superiores em relação às demais fontes de fibra. Foi possível observar efeito interativo processamento*tratamento $(\mathrm{P}=$ $0,0169)$ para o coeficiente de digestibilidade aparente da FDA. O grupo controle e o grupo feno de Tifton 85 , tanto extrusado quanto peletizado, apresentaram melhores resultados de digestibilidade da fibra em relação aos demais. 0 resultado da interação processamento*tratamento mostra que o tratamento com melhor coeficiente de digestibilidade aparente da FDA foi o feno de Tifton 85 extrusado (57,59\%) dentre as dietas processadas. Os resultados inferiores referentes à digestibilidade aparente dos nutrientes para o tratamento com capim elefante estão relacionados à quantidade de carboidratos não estruturais e ao teor da fração fibrosa presente na dieta em relação aos demais tratamentos. Em geral, os constituintes fibrosos (FDN, FDA e Lignina) são correlacionados negativamente com a digestibilidade. No presente trabalho, a dieta completa peletizada ou extrusada não interferiu na digestibilidade aparente dos nutrientes, sendo que a fonte de fibra com maior FDA (capim elefante) resultou em menores coeficientes de digestibilidade aparente da dieta em relação às demais fontes de fibra.

Palavras-chave: Alimentação. Cavalo. Dieta completa. 